DOI: https://doi.org/10.35961/jppmkepri.v1i1.175

\title{
Pemanfaatan E-Learning Bagi Guru MGMP PAI Pada Masa Covid-19 Di Kabupaten Bintan Kepulauan Riau
}

\author{
Ramandha Rudwi Hantoro ${ }^{1 *}$, Dwi Vita Lestari. $\mathrm{S}^{2}$, Ediyansyah ${ }^{3}$, Zulhamdan $^{4}$, Sudanto ${ }^{5}$ \\ 1, 2, 3, 4, 5 STAIN Sultan Abdurrahman Kepulauan Riau, Bintan, Kepulauan Riau, 29123, Indonesia \\ *ramandha@stainkepri.ac.id
}

\begin{abstract}
Abstrak
Sejak merebaknya wabah pandemi corona virus disease (Covid-19) di seluruh dunia memaksa banyak sekolah di Indonesia melaksanakan pembelajaran secara online di rumah. Google salah satu aplikasi online yang memiliki banyak fasilitas yang dapat digunakan untuk pembelajaran untuk guru dan siswa secara online, diantaranya google meet dan google classroom. Google meet dan google classroom menyediakan banyak fasilitas untuk pembelajaran yang aman dan mudah digunakan untuk komunikasi antara guru dan murid. Pengabdian kepada masyarakat bertujuan untuk mengenalkan media pembelajaran menggunakan google meet dan google classroom untuk digunakan pembelajaran online kepada guru Musyawarah Guru Mata Pelajaran Pendidikan Agama Islam (MGMP PAI) Kabupaten Bintan Kepulauan Riau. Pelatihan dilaksanakan secara daring menggunakan Whatsapp grup yang diikuti oleh 30 orang peserta guru perwakilan dari seluruh SMP Kabupaten Bintan.
\end{abstract}

Kata kunci: E-learning; google meet; google classroom; covid-19.

\begin{abstract}
Since the outbreak of the pandemic corona virus disease (Covid-19) around the world has forced many schools in Indonesia to carry out online learning at home. Google is an online application that has many facilities that can be used for learning for teachers and students online, including Google Meet and Google Classroom. Google Meet and google classroom provide many facilities for safe and easy-to-use learning for communication between teacher and student. Community service aims to introduce learning media using google meet and google classroom to be used online learning to teachers of the Islamic Religious Education Consultation Subjects (MGMP PAI) in Bintan Islands, Riau Islands. The training was carried out online using Whatsapp group, which was attended by 30 representative teacher participants from all SMP Bintan Regency
\end{abstract}

Keywords: e-learning; google meet; google classroom; covid-19. 


\section{Pendahuluan}

Menyebarnya wabah virus corona virus disease (Covid-19) memiliki dampak yang signifikan pada dunia pendidikan, termasuk di Indonesia. Demi mencegah peyebaran Covid-19 pemerintah Indonesia melalui Kemendikbud menerbitkan Surat Edaran Nomor 15 th 2020 tentang Pedoman Penyelenggaraan Belajar dari Rumah Dalam Masa Darurat Penyebaran Covid-19. Pasca dikeluarkan SE No. 15 th 2020 oleh Kemendikbud, seluruh sekolah dari tingkat dasar hingga menengah memberlakukan pembelajaran jarak jauh via online.

Di Kabupaten Bintan, dikutip dari Surat Edaran Bupati Bintan Provinsi Kepulauan Riau, Nomor: 440/DISDIK/165, Bupati Bintan telah mengeluarkan himbauan tentang pencegahan penyebaran corona virus disease (Covid-19) di lingkungan Dinas Pendidikan Kabupaten Bintan, yang mulai berlaku pada tanggal 17 sampai dengan 29 Maret 2020. Ada 2 poin dari himbauan tersebut terkait pendidikan yaitu, himbauan untuk kegiatan belajar mengajar semua jenjang dilakukan dirumah peserta didik masing-masing dan para guru maupun pengajar dapat melakukan proses belajar mengajar melalui media daring (online).

E-learning merupakan seluruh teknologi pembelajaran yang mendukung kegiatan belajar-mengajar seperti audio dan visual, saluran telepon, satelit telekonferen, ataupun sambungan transmisi yang biasa dikenal dengan pelatihan berbasis web yang berhubungan dengan kursus secara online (Sekartawi, 2007). Elearning juga mampu dimanfaatkan untuk memperdalam pemahaman materi dan memperluas bacaarn materi (Hanum, 2013). Google meet dan google classroom merupakan dua aplikasi yang relevan digunakan untuk pembelajaran selama masa covid-19. Google classroom mempermudah guru dalam menyampaikan materi pembelajaran kepada peserta didik secara tepat dan akurat (Hakim, 2016). Dalam google classroom guru dapat mendistribusikan tugas, submit tugas bahkan guru juga dapat menilai tugas yang dikumpulkan secara langsung (Herman dalam Hammi, 2017). Oleh karena itu, guru tak perlu disibukkan lagi bagaimana cara menyimpan dan mengelola nilai karena dalam google classroom juga difasilitasi rekap nilai secara otomatis dan penyimpanan langsung dalam google drive.

Dengan adanya fasilitas yang disediakan google meet dan google classroom yang mudah dan efisien, penggunaan e-learning dalam proses pembelajaran bagi guru-guu MGMP PAI Kabupaten Bintan belum maksimal. Selama ini guru PAI Kabupaten Bintan lebih sering memanfaatkan Whatsapp grup untuk pembelajaran online yang dirasa kurang tepat dan efisien. Berdasarkan uraian di atas, pengenalan dan penggunaan aplikasi google meeting dan google classroom bagi guru-guu MGMP PAI Kabupaten Bintan untuk menunjang kegiatan pembelajaran sangatlah tepat.

\section{Metode}

Metode yang digunakan dalam pengabdian ini adalah Assed Bassed Community-Drivern Development yang berupaya pada pemberdayaan masyarakat akan asset-aset yang dimillikinya baik yang bersifat materi maupun immateri sebagai modal awal untuk mengembangkan masyarakat tersebut. Adapun rangkaian tahapan pelaksanaan KKN dengan metode Assed Bassed Community-Drivern Development (ABCD) meliputi; inkulturasi, discovery, design, define, dan refleksi. Tahapan-tahapan tersebut secara lebih jelas dijabarkan dalam tabel berikut ini; 
Tabel 1

Tahapan Pelaksanaan

\begin{tabular}{|c|c|c|}
\hline No & Tahapan & Kegiatan \\
\hline 1. & Inkulturasi (Perkenalan) & $\begin{array}{l}\text { Pada tahap ini, tim Pengabdian kepada Masyarakat } \\
\text { (PkM) STAIN Sultan Abdurrahman Kepri } \\
\text { melakukan koordinasi dengan Dinas Pendidikan } \\
\text { Kabupaten Bintan sebagai fasilitator terhadap guru } \\
\text { mitra, yaitu guru Pendidikan Agama Islam se- } \\
\text { Kabupaten Bintan. } \\
\text { Langkah ini dilakukan sebagai bentuk komunikasi } \\
\text { awal antara tim PkM STAIN Sultan Abdurrahman } \\
\text { dengan mitra pengabdian untuk membangun trust } \\
\text { (kepercayaan) Majelis Guru Mata Pelajaran (MGMP) } \\
\text { Pendidikan Agama Islam (PAI) Kabupaten Bintan. } \\
\text { Tahap inkulturasi dilakukan agar guru MGMP PAI } \\
\text { Kabupaten Bintan mengetahui maksud dan tujuan } \\
\text { kegiatan PkM oleh tim STAIN Sultan Abdurrahman } \\
\text { Kepri. }\end{array}$ \\
\hline 2. & Discovery (Mengungkapkan Informasi) & $\begin{array}{l}\text { Tim melakukan penggalian informasi sebagai upaya } \\
\text { untuk mendapatkan info-info penting dari guru } \\
\text { MGMP PAI Kab. Bintan terkait pelaksanaan } \\
\text { pendidikan mata pelajaran PAI di seluruh SMP } \\
\text { Kabupaten Bintan masa Covid-19. }\end{array}$ \\
\hline 3. & $\begin{array}{l}\text { Design (mengetahui aset dan } \\
\text { mengidentifikasi peluang) }\end{array}$ & $\begin{array}{l}\text { Tahap ini tim menyusun rencana kegiatan sebagai } \\
\text { bentuk konkrit dari hasil informasi yang didapat dari } \\
\text { guru MGMP PAI Kab. Bintan terkait pelaksanaan } \\
\text { pendidikan mata pelajaran PAI di seluruh SMP } \\
\text { Kabupaten. Bintan masa Covid-19. }\end{array}$ \\
\hline 4. & $\begin{array}{l}\text { Define } \\
\text { (mendukung keterlaksanaannya } \\
\text { program kerja }\end{array}$ & $\begin{array}{l}\text { Setelah mengetahui aset dan identifikasi peluang pada } \\
\text { tahap ke-3. Tim Pengabdian kepada masyarakat } \\
\text { (PkM) STAIN Sultan Abdurrahman menentukan } \\
\text { kegiatan, yaitu menyelenggarakan workshop } \\
\text { terhadap guru-guru PAI tentang pemanfaatan google } \\
\text { classroom dan zoom sebagai media pembelajaran } \\
\text { masa Covid-19. }\end{array}$ \\
\hline 5. & Refleksi & $\begin{array}{l}\text { Setelah melakukan langkah-langkah di atas, guru-guru } \\
\text { menemukan potensi yang mereka miliki. Mereka } \\
\text { dapat memanfaatkan smarthphone dan laptop untuk } \\
\text { pembelajaran } \\
\text { melalui aplikasi classroom dan zoom pada mata } \\
\text { pelajaran PAI. }\end{array}$ \\
\hline
\end{tabular}




\section{Hasil dan Pembahasan}

\section{Persiapan kegiatan}

Persiapan dilakukan dua minggu sebelum pelaksanaan dengan berkoordinasi dengan Ketua MGMP PAI Kab. Bintan dan difasilitasi oleh Disdik Kab. Bintan dengan tetap mematuhi peraturan social distancing sebagaimana yang ditetapkan oleh pemerintah. Persiapan yang dilakukan diantaranya menentukan peserta pelatihan sejumlah 30 orang guru untuk dimasukkan ke dalam Grup WA. Kemudian tim PkM dari STAIN Sultan Abdurrahman Kepulauan Riau membuat modul dan materi pelatihan untuk dibagikan di dalam Grup Whatsapp.

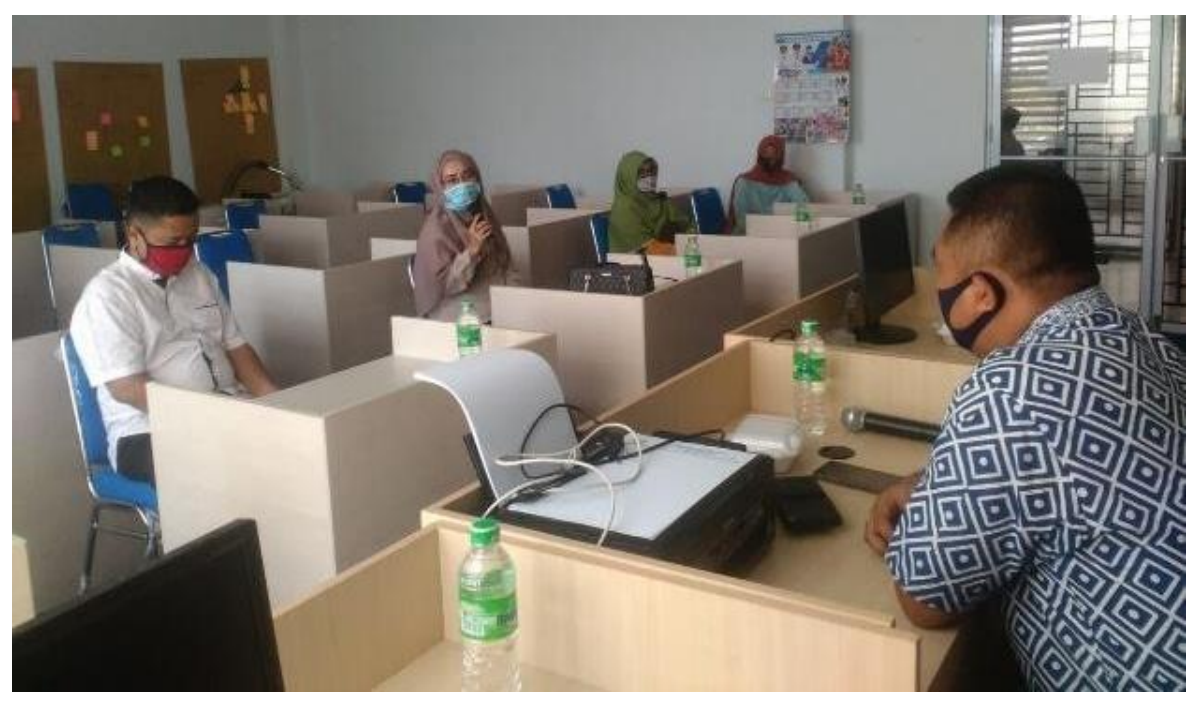

Gambar 1. Koordinasi dengan Ketua MGMP PAI difasilitasi Disdik Bintan

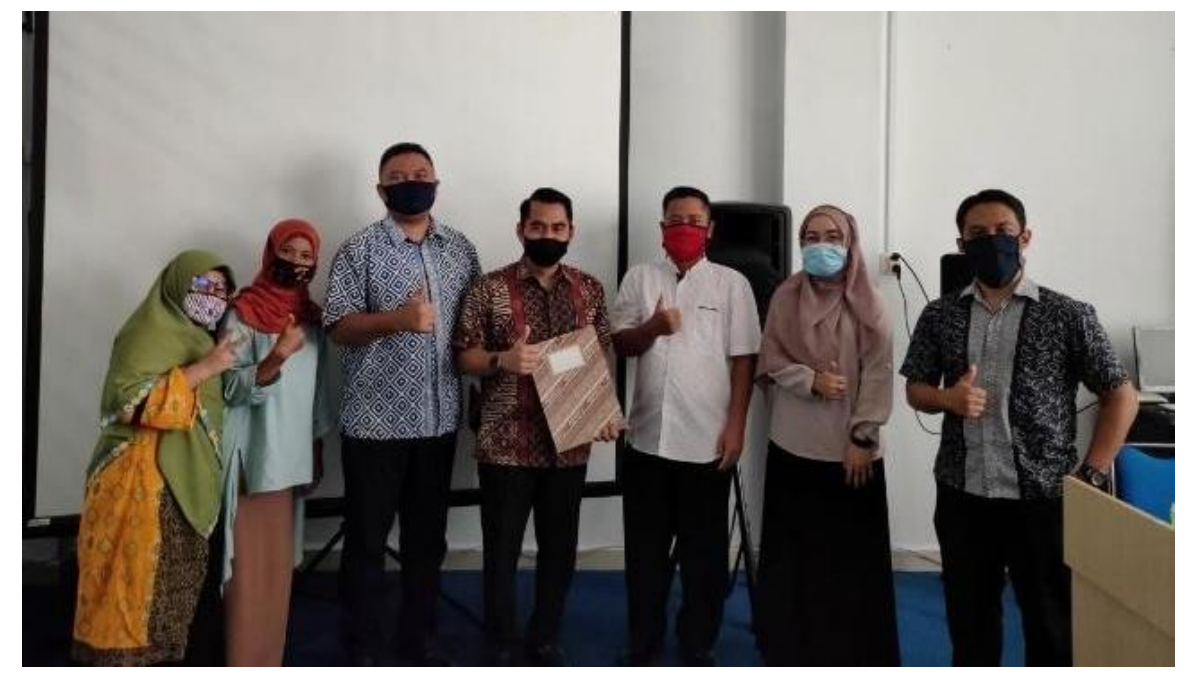

Gambar 2. MoU prodi MPI dengan Disdik Bintan dan MGMP Guru PAI 


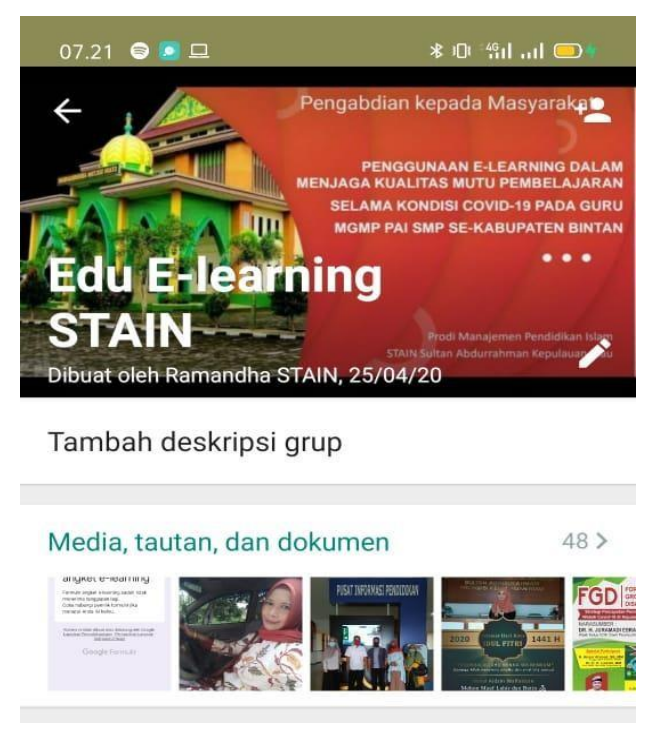

Gambar 3. Grup pelatihan Whatsapp

\section{Pelaksanaan Kegiatan}

Kegiatan pelatihan e-learning google meet dan classroom kepada guru MGMP PAI Kabupaten Bintan ini merupakan salah satu kegiatan pengabdian masyarakat yang dilakukan oleh tim dosen Program Studi Manajemen Pendidikan Islam STAIN Sultan Abdurrahman Kepulauan Riau. Kegiatan Pelatihan elearning kepada Guru MGMP PAI Kabupaten Bintan dilakukan selama 1 hari dimulai dari pukul 08.00 hingga 12.00 WIB secara online melalui Whatsapp grup pada tanggal 11 Mei 2020. Kegiatan diawali dari cek kesiapan peserta dan megisi absensi secara online pada pukul 08.00 WIB. Peserta yang melakukan absensi online sebanyak 22 orang peserta, 8 orang guru lainnya memiliki masalah gangguan signal. Setelah registrasi dimulai dengan kata sambutan dari ketua Prodi Manajemen Pendidikan Islam STAIN Sultan Abdurrahman Kepulauan Riau dilanjutkan dengan materi pelatihan google meet dan classroom.

Dalam pembukaan disampaikan tentang pelaksanaan pelatihan dengan sistem daring/online oleh tim pengabdian dari prodi Manajemen Pendidikan Islam. Kemudian dijelaskan juga tentang tujuan di laksanakannya pelatihan e-learning secara oline kepada guru-guru PAI Kabupaten Bintan setelah itu dilanjutkan dengan materi pelatihan oleh pemateri-pemateri dari tim pengabdian Prodi MPI STAIN Sultan Abdurrahman Kepulauan Riau. 


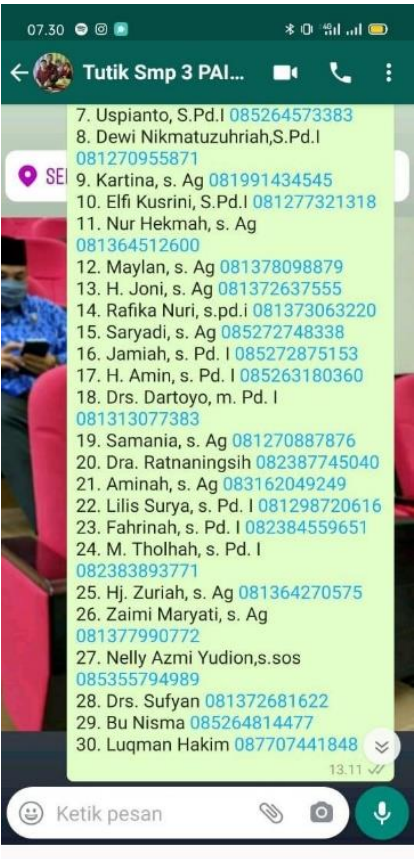

Gambar 4. Daftar Absen

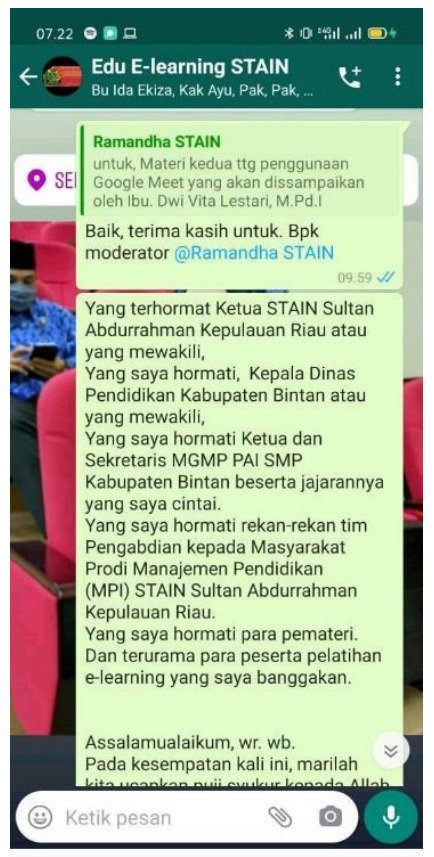

Gambar 5. Pembukaan pelatihan online via WA Group

Penyampaian materi pelatihan menggunakan dua metode, yaitu: memberikan soft copy baik dalam bentuk pdf maupun ppt dan yang kedua penjelasan melalui voice recoder. Setelah pemateri menyampaikan materinya peserta diberi kesempatan untuk bertanya dan berdiskusi tentang materi yang disampaikan. Peserta dibimbing oleh pemateri bagaimana cara menggunakan aplikasi google meet dan classroom via online dan juga diberi arahan bagaimana cara menggunakannya. Para guru menyampaikan bahwa dengan menggunakan aplikasi tersebut guru dapat lebih efektif dan efisien dalam memberikan penilaian dan menyimpan tugas siswa-siswanya tanpa harus takut hilang dan rusak karena aman dan mudah untuk diakses dimana saja dan kapan saja.

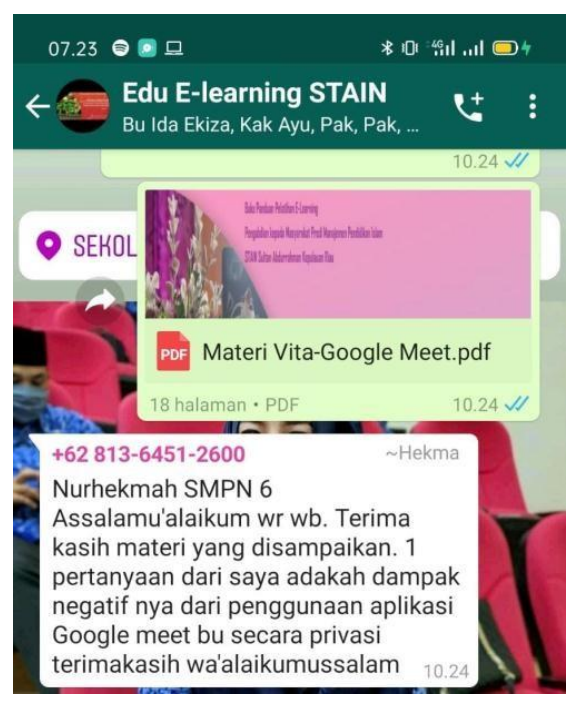

Gambar 6. Materi pelatihan

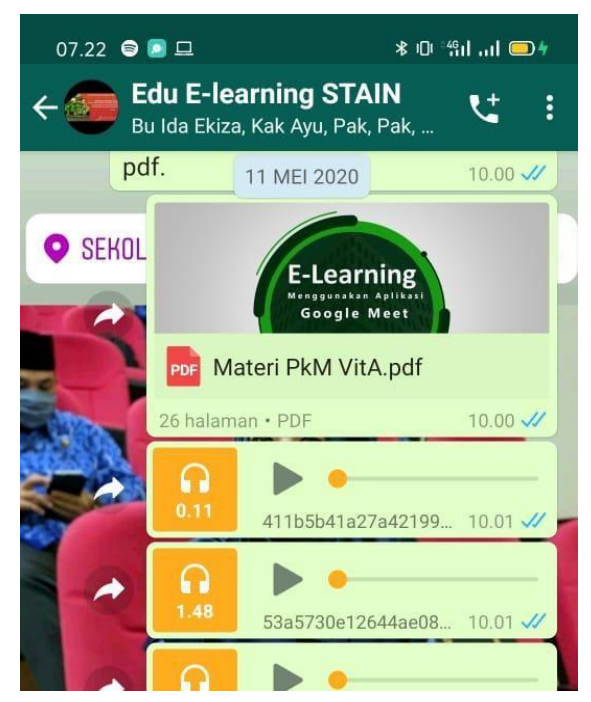

Gambar 7. Materi dengan voice recorder 
Supaya mengetahui hasil dari pelatihan ini dan evaluasi terhadap kegriatan pelatihan maka tim dosen membuat kuisioner melalui google form. Adapun hasil dari kuisioner ditampilkan melalui gambar berikut:

1. Apakah Pelatihan pembelajaran e-learning bermanfaat untuk Bapak/ibu?

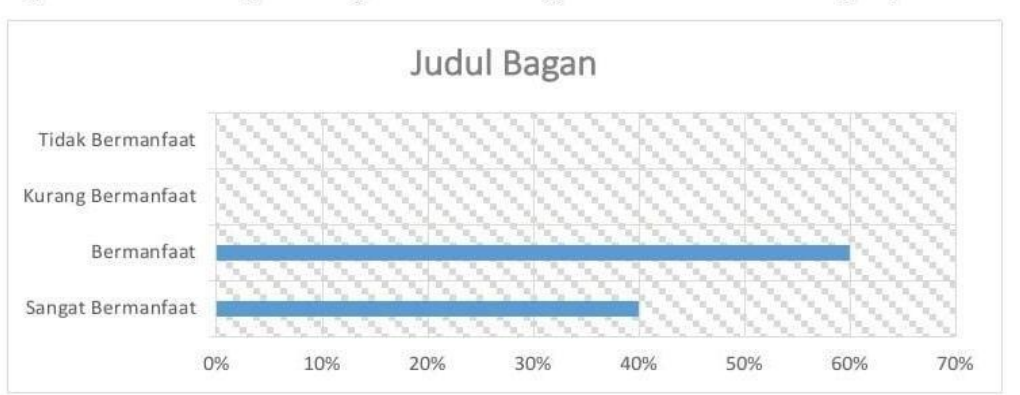

2. Apakah dalam pelaksanaan pelatihan ini meningkatkan pemahaman Bapak/It dalam menggunakan e-learning Google Classroom dan Google meet?

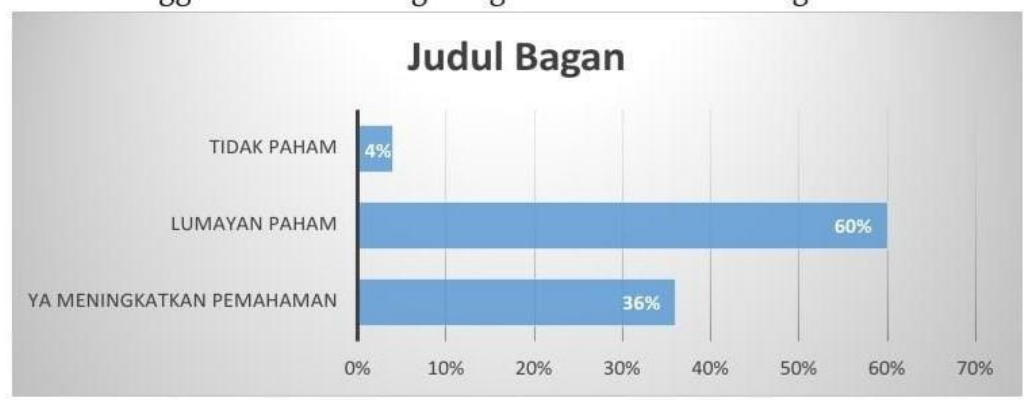

3. Setelah mengikuti pelatihan e-learning Google Classroom dan Google meet, Apakah Bapak/Ibu tertarik menerapkan media pembelajaran tersebut pada proses belajar Bapak/Ibu ke depannya?

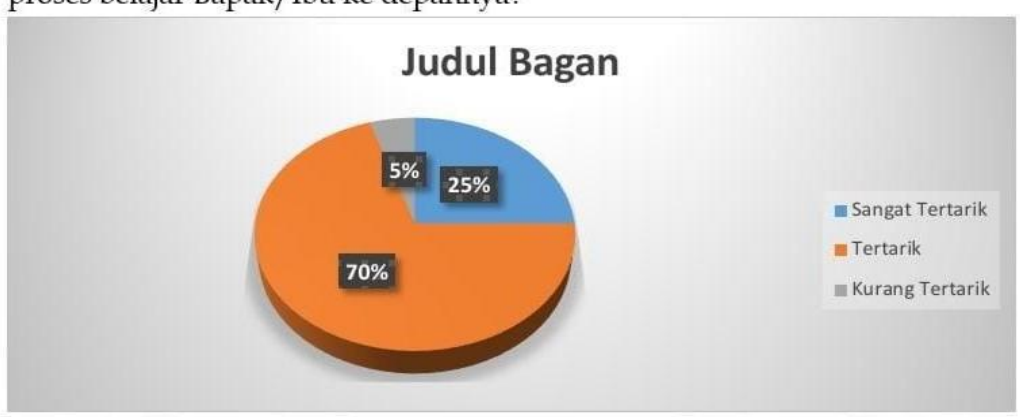

Gambar 8. Hasil kuisioner pelatihan e-learning

Hasil dari kuisioner menunjukkan bahwa sebanyak $60 \%$ peserta pelatihan menyatakan bahwa pelatihan bermanfaat, sedangkan $40 \%$ sisanya menyatakan pelatihan e-learing sangat bermanfaat. Hal ini meunjukkan bahwa guru MGMP PAI sangat membutuhkan pelatihan e-learning untuk pembelajaran. Dari segi pemahaman sebanyak $96 \%$ peserta meyatakan kegiatan pelatihan meningkatkan pemahaman cara penggunaannya. Peserta juga memiliki ketertarikan untuk meggunakan google meet dan classroom dalam proses pembelajaran khususnya saat pandemi Covid-19.

\section{Pasca Kegiatan}

Tahap selanjutnya setelah berakhirnya kegiatan adalah pembuatan sertifikat peserta dan pemateri pelatihan, distribusi sertifikat baik peserta dan pemateri, pembuatan laporan akhir pengabdian kepada masyarakat. Sertifikat pelatihan yang dibuat adalah e-sertifikat yang didistribusikan melalui akun Whatsapp mengingat masih dalam kondisi social distancing pandemi corona covid-19. 


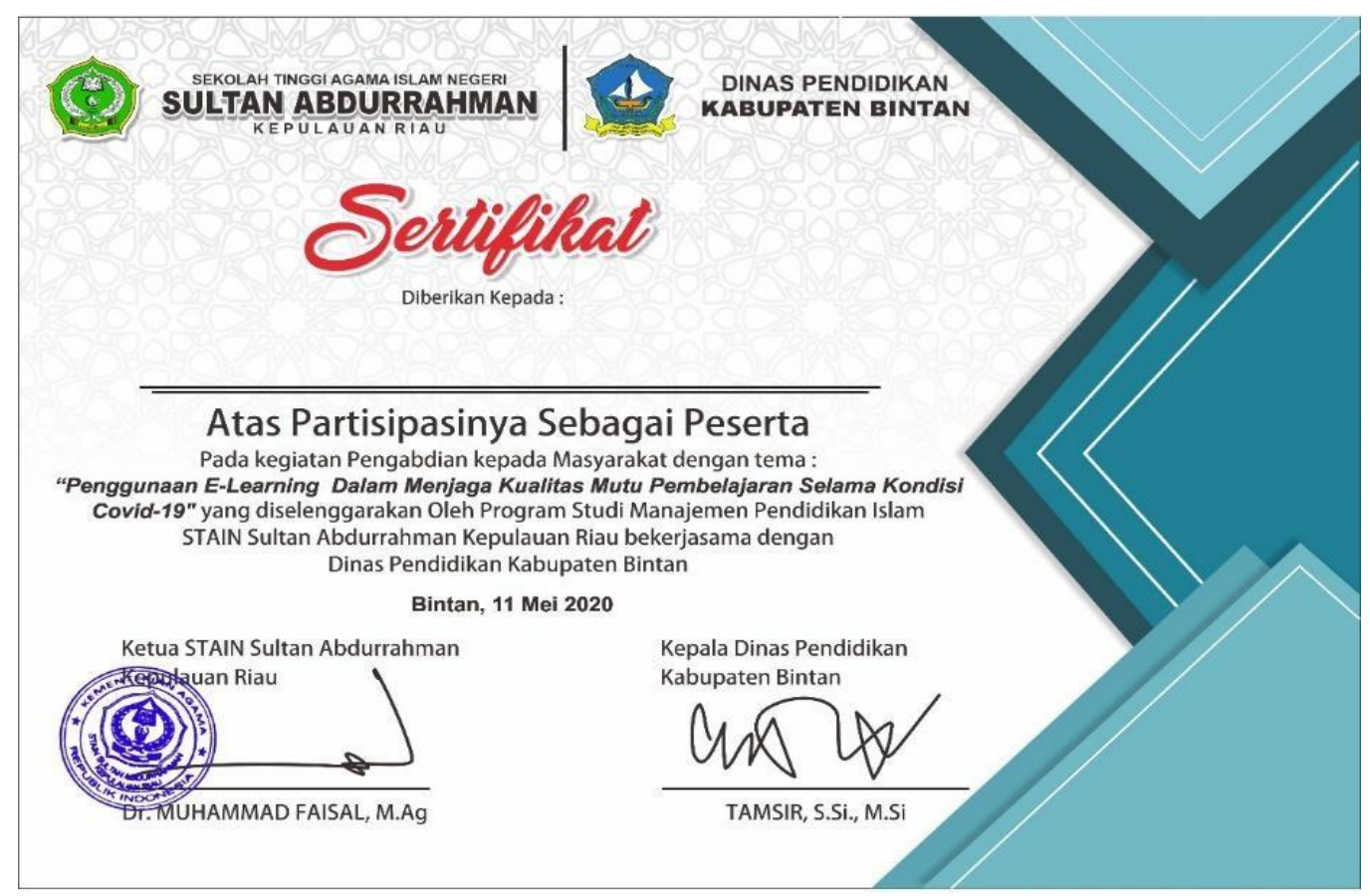

Gambar 9. E-serfifikat pelatihan

\section{Kesimpulan}

Dari kegiatan pengabdian masyarakat pelatihan e-learning yang dilaksanakan oleh tim dosen program studi Manajemen Pendidikan Islam STAIN Sultan Abdurrahman Kepulauan Riau bagi guru MGMP PAI Kabupaten Bintan, dapat ditarik kesimpulan bahwa google meet dan google classroom dapat digunakan sebagai alternatif pembelajaran online yang mudah, efektif dan efisien sehingga dapat diterapkan oleh guru dan murid selama masa Covid-19. Hasil evaluasi dari pelatihan e-learning berdasarkan kuesioner menunnjukkan bahwa peserta pelatihan yaitu Guru PAI Kabupaten Bintan memiliki antusias yang tinggi dalam mengikuti pelatihan e-learning. Pembelajaran secara online tidak lagi menjadi hambatan bagi guruguru PAI untuk tetap memberikan tugas dan materi kepada siswa-siswanya.

\section{Saran}

Pihak sekolah perlu memberikan fasilitas pelatihan kepada para guru khususnya guru PAI tentang elerning pembelajaran. Selain itu perlu bagi pihak penyelenggara pendidikan perlu mempersiapkan infrastruktur jaringan yang baik dengan penyediaan server atau penyedia hosting yang bisa dikelola secara profesional. Bagi pihak sekolah ada baiknya siswa-siswanya dibuatkan account email agar dapat mempermudah dalam pembelajaran e-learning.

\section{Ucapan Terimakasih}

Penulis mengucapkan terima kasih kepada STAIN Sultan Abdurrahman Kepulauan Riau yang telah memberi dukungan moral dan dana terhadap program pengabdian masyarakat ini. Juga kepada Dinas Pendidikan Kabupaten Bintan selaku mitra dalam pengabdian kepada masyarakat dan juga para guru MGMP Pendidikan Agama Islam (PAI) Kabupaten Bintan atas partisipasinya dalam kegiatan ini. 


\section{Referensi}

Hakim, A.B., (2016). Efektifitas Penggunaan E-Learning Moodle, Google Classroom Dan Edmodo. ISTATEMENT: Information System and Technology Management, 2(1).

Hammi, Zedha. (2017). Implementasi Google Classroom Pada Kelas XI IPA MAN 2 Kudus. Universitas Negeri Semarang

Hanum, N.S., (2013). Keefetifan E-Learning sebagai Media Pembelajaran (Studi Evaluasi Model Pembelajaran E-Learning SMK Telkom Sandhy Putra Purwokerto). Jurnal Pendidikan Vokasi, 3(1).

Soekartawi. (2007). Merancang dan Menyelenggarakan E-Learning. Yogyakarta: Ardana Media. 